\title{
Pola arus permukaan saat surut di sekitar muara Sungai Malalayang, Teluk Manado
}

\author{
Pattern of surface currents during ebb tides near Malalayang River's mouth, Manado Bay
}

Yotam N. KAMAT*, PATRICE N.I KALANGI dan MetA S. SOMPIE

Program Studi Pemanfaatan Sumberdaya Perikanan, Fakultas Perikanan dan Ilmu Kelautan, Universitas Sam Ratulangi, Manado 95115

\begin{abstract}
Coastal waters are one of waters areas that can be utilized for various purposes like fishery activities and tourism by and/or for a community. This utilization needs oceanographic information, especially the pattern of water mass flow. This research is descriptive in nature, i.e. to describe clearer about certain condition. Data collecting was done in October 2014 at coastal waters of Malalayang River's mouth. Flow maps indicated that at the beginning of ebb tide period, water mass tend to flow to the west, and then turned to the east at the rest of period.
\end{abstract}

Keywords: surface currents, Lagrangian method, Malalayang River, Manado Bay

\begin{abstract}
ABSTRAK
Perairan pantai merupakan salah satu wilayah perairan yang dapat digunakan untuk berbagai kepentingan seperti usaha perikanan dan pariwisata oleh dan atau bagi masyarakat. Pemanfaatan ini sangat membutuhkan informasi oseanografi, khususnya pola pergerakan massa air. Penelitian ini bersifat deskriptif, yakni penelitian yang bertujuan untuk menggambarkan dengan lebih jelas tentang kondisi tertentu. Pengumpulan data dilakukan dengan metode Lagrangian. Penelitian ini dilakukan pada bulan Oktober 2014 di perairan muara Sungai Malalayang. Hasil pemetaan menunjukkan bahwa pada awal periode air surut, massa air cenderung bergerak ke arah barat, tetapi kemudian berbalik ke arah timur di sisa periode.
\end{abstract}

Kata-kata kunci: arus permukaan, metode Lagrangian, Sungai Malalayang, Teluk Manado

\section{PENDAHULUAN}

Perairan pantai merupakan salah satu wilayah perairan yang dapat digunakan untuk berbagai kepentingan seperti usaha perikanan dan pariwisata. Dalam memanfaatkan sumber daya ikan, salah satu faktor yang perlu diketahui adalah parameter oseanografi, misalnya arus atau pola aliran air. Menurut Gunarso (1985), arus sangat mempengaruhi metode penangkapan ikan dan kontruksi alat tangkap ikan. Arus yang kuat, misalnya, akan membuat alat tangkap terhanyut dan/atau terangkat dari posisi seharusnya sehingga tidak dapat menangkap ikan secara efektif.

Arus berpengaruh juga terhadap penyebaran organisme laut (Garrison, 2004). Phytoplankton yang tidak mampu bergerak-pindah sendiri akan

\footnotetext{
*Penulis untuk penyuratan; email: nikolaskamat@yahoo.com
}

berdistribusi sesuai dengan pola arus. Distribusi phytoplankton ini selanjutnya akan berpengaruh terhadap distribusi organisme lainnya seperti ikan, yang terhubung dalam rantai makanan. Selain berpengaruh terhadap distribusi, arus juga berpengaruh terhadap arah renang ikan. Laevastu dan Hayes (1982) menyatakan bahwa ikan-ikan cenderung bergerak melawan arah arus pada siang hari tapi menghanyut dengan arus pada malam hari.

Pola aliran juga akan berpengaruh terhadap sebaran benda-benda atau zat-zat tertentu di perairan. Bahan-bahan polutan konservatif seperti botol-botol plastik misalnya mungkin akan mengumpul pada suatu tempat atau menyebar merata di suatu perairan bergantung pada pola arus (Kalangi, 2000).

Ada dua metode untuk menggambarkan pola pergerakan massa air di suatu perairan, yaitu metode Eulerian dan metode Lagrangian (Pickard 
dan Emery, 1990). Metode Lagrangian telah digunakan lebih dari tiga dekade dan masih digunakan hingga saat ini (Pickard dan Emery, 1990; van Aken, 2002; Gerin, 2013). Penelitian dengan pelampung arus telah dilakukan dalam skala oseanik sampai skala teluk kecil. Berdasarkan lapisan perairan, penelitian juga telah dilakukan untuk dua-tiga meter lapisan permukaan maupun pada lapisan lebih dari $10 \mathrm{~m}$ (van Aken, 2002).

Pola pergerakan massa air di perairan pantai dipengaruhi oleh berbagai faktor fisik. Faktorfaktor tersebut antara lain adalah angin, arus pasang surut (pasut), dan volume aliran sungai (Geyer, 1997; Lewis, 1997). Angin akan mendorong permukaan air untuk ikut bergerak bersama. Menurut Knauss (1997), angin akan memberikan kecepatan pada arus permukaan sebesar sekitar $2 \%$, dan arah angin sedikit dibelokkan ke kanan (pada belahan bumi utara) sebagai efek Coriolis. Di daerah estuari atau muara sungai, arah dan kecepatan angin dapat mendorong atau menahan air untuk keluar dari daerah estuari, atau sebaliknya untuk masuk estuari (Geyer, 1997). Selanjutnya Garvine (1974) menunjukkan bahwa perairan laut di sekitar muara sungai sangat dinamis oleh karena buoyancy dan momentum air sungai.
Di Teluk Manado, beberapa informasi kondisi oseanografi fisik telah dipublikasikan (Rampengan, 2009; Tulengen dkk, 2012). Rampengan (2009) telah menggambarkan pola arus di Teluk Manado yang ditimbulkan oleh pasang surut. Dia menyatakan bahwa pada bagian tengah mulut teluk arus pasut bersifat rectilinear; sedangkan di perairan pantai bagian selatan teluk, air mengalir ke arah timur pada saat surut dan sebaliknya pada saat pasang. Sedangkan untuk perairan yang sangat dekat dengan garis pantai, Tulengen dkk (2012) menunjukkan kekompleksannya.

Penelitian ini bertujuan untuk mengetahui pola pergerakan massa air di perairan sekitar muara Sungai Malalayang, khususnya pada saat air bergerak surut. Penelitian ini dilaksanakan pada 22-24 Oktober 2014 saat spring tides (bulan baru)

\section{METODE PENELITIAN}

Penelitian ini bersifat deskriptif, yakni penelitian yang bertujuan untuk menggambarkan yang lebih jelas tentang kondisi tertentu (Nasution, 2009), dalam hal ini pola arus yang ada di muara Sungai Malalayang. Pengumpulan data dilakukan dengan metode survei.

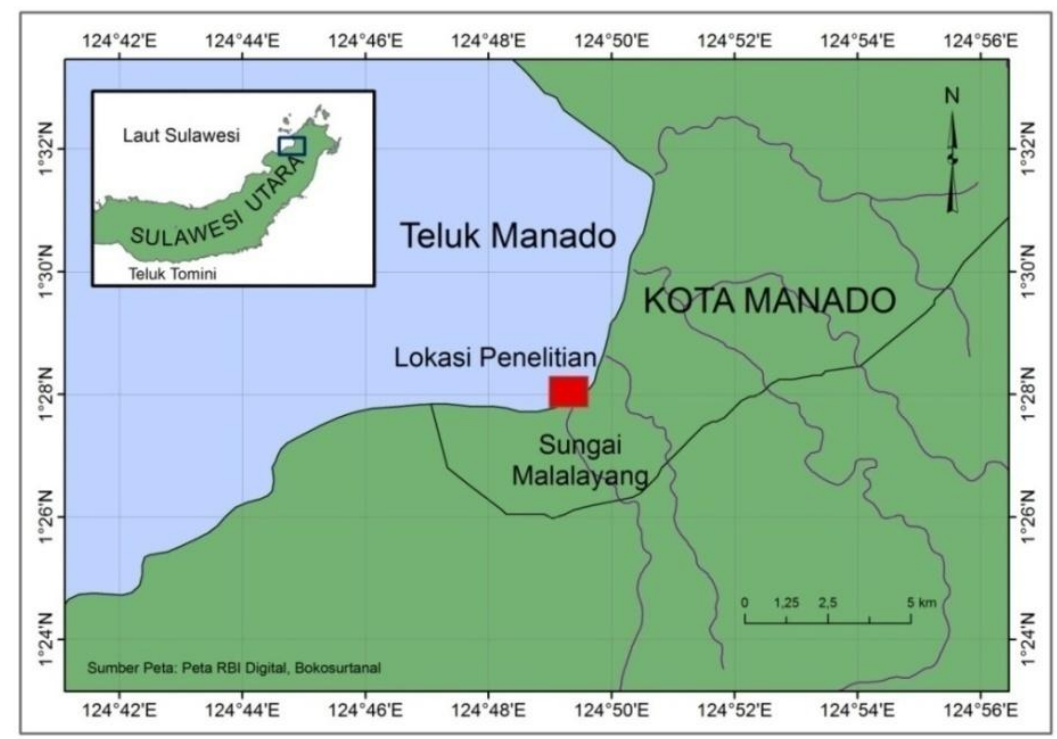

Gambar 1. Lokasi penelitian 
Data yang dikumpulkan mencakup data posisi pelampung arus dan tinggi muka air laut. Penentuan posisi pelampung dan pembacaan tinggi muka air pada palem pasut dilakukan pada interval waktu tertentu.

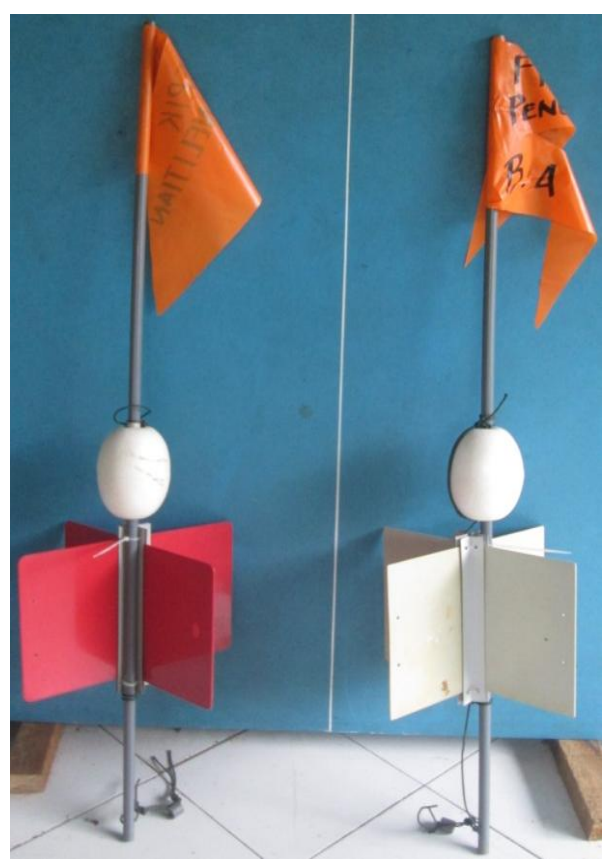

Gambar 2. Pelampung arus

Penelitian ini mengoperasikan dua kumpulan pelampung arus yang dilepas pada waktu yang berbeda. Kumpulan pelampung arus yang pertama (yang disebut kumpulan A) terdiri atas lima unit pelampung dilepas pada suatu titik di muara sungai pada saat air mulai bergerak surut. Kumpulan kedua (yang disebut kumpulan B) yang terdiri atas empat pelampung arus dilepas di suatu titik di muara sungai pada sekitar pertengahan waktu air surut. Pelampung-pelampung ini kemudian diambil posisinya satu per satu dengan menggunakan GPS dari atas perahu pelang bermotor. Interval pengambilan posisi lebih singkat pada awal-awal pengamatan dibanding pada saat-saat pelampung arus sudah agak jauh dari muara. Interval pengukuran sekitar 10 menit, 20 menit, 30 menit dan kemudian 1 jam. Posisiposisi tersebut disimpan dalam memori GPS sebagai waypoints. Bersamaan dengan penentuan posisi, jam penentuan posisi untuk masing-masing pelampung dicatat. Dalam keadaan pelampung telah memasuki perairan yang sulit dijangkau dengan perahu atau sudah keluar dari wilayah pengamatan, pelampung-pelampung diangkat dan diposisikan lagi di suatu tempat sebagai awal pengamatan baru.

Perubahan tinggi muka air yang berkaitan dengan pasang surut diukur dengan palem pasut. Palem ini ditancapkan pada perairan yang tidak menjadi kering pada saat surut terendah. Pembacaan tinggi pasang surut dilakukan setiap sekitar 15 menit selama siang hari pada saat pengoperasian pelampung-pelampung arus.

\section{HASIL DAN PEMBAHASAN}

\section{Pasang surut}

Tinggi pasang surut merupakan salah satu faktor penting dalam membentuk pola arus di suatu perairan. Hasil pengukuran tinggi permukaan air selama survei arus Lagrangian ditampilkan pada Gambar 6. Pasang surut di daerah ini bersifat semidiurnal (harian ganda) (Pond and Pickard, 1983) dengan tinggi gelombang pasut sekitar 1,80 m.

\section{Pola pergerakan massa air}

Data posisi untuk setiap pelampung arus berdasarkan kumpulan ditampilkan dalam bentuk peta (Gbr. 4). Jalur dari setiap pelampung dalam satu kumpulan dapat saling menyilang sehingga sulit untuk diikuti dalam gambar. Untuk memudahkan, posisi rata-rata kumpulan digunakan untuk merepresentasikan pergerakan massa air untuk setiap kumpulan pelepasan. Pergerakan massa air rata-rata ini disajikan pada Gbr. 5-8. Nomornomor pada jalur pergerakan menunjukkan urutan waktu pengamatan.

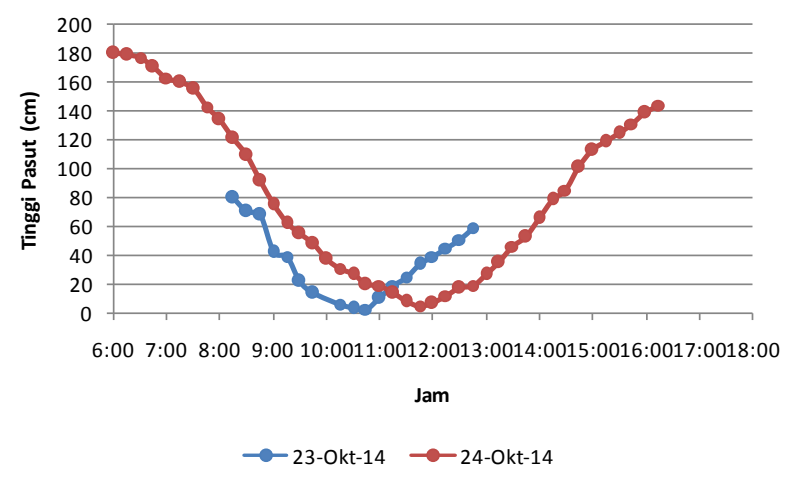

Gambar 3. Tinggi pasang surut saat pengoperasian pelampung-pelampung arus 
Y.N. Kamat dkk.
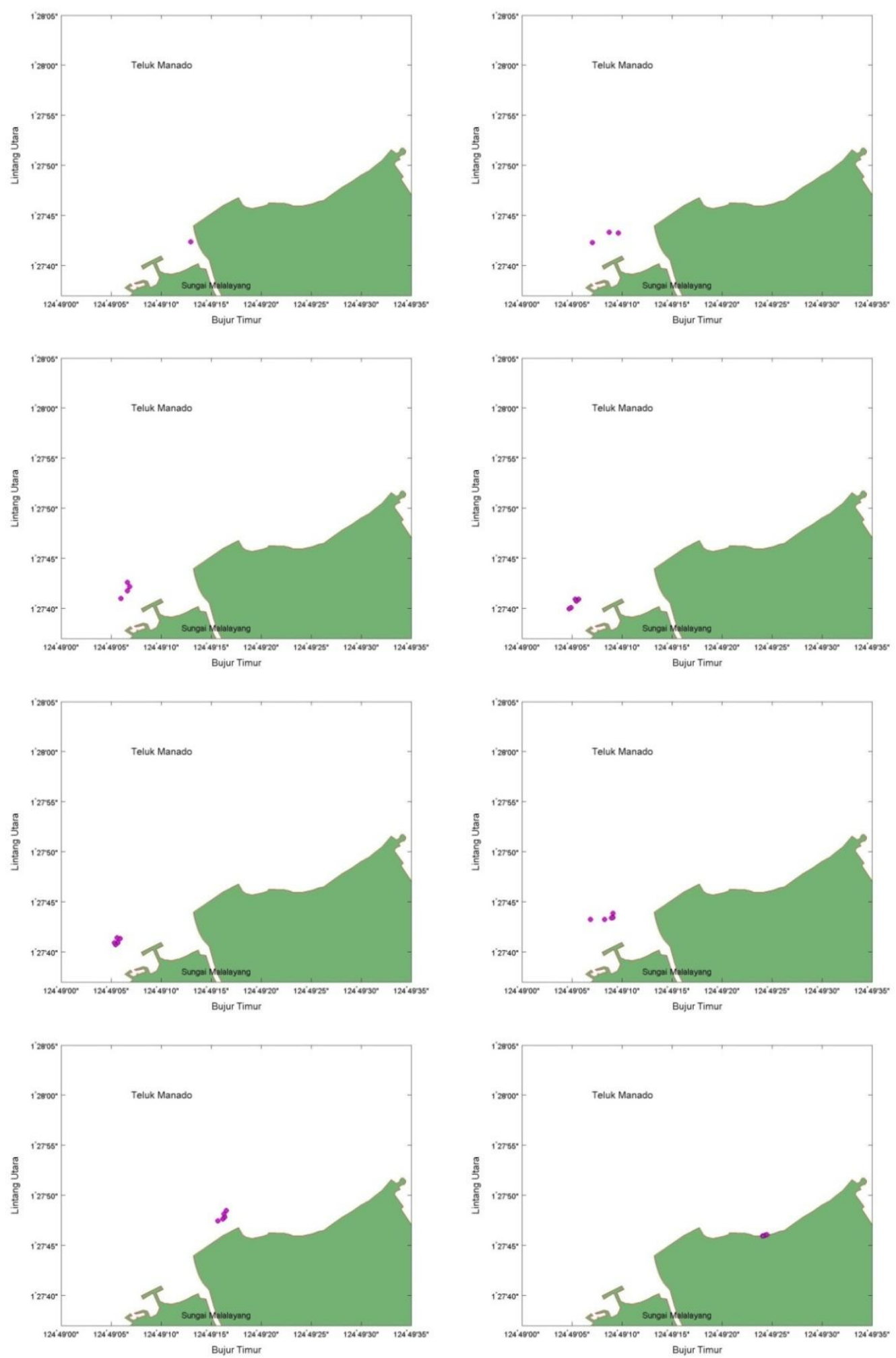

Gambar 4. Posisi kumpulan pelampung arus (A) tanggal 23 Oktober 2014 


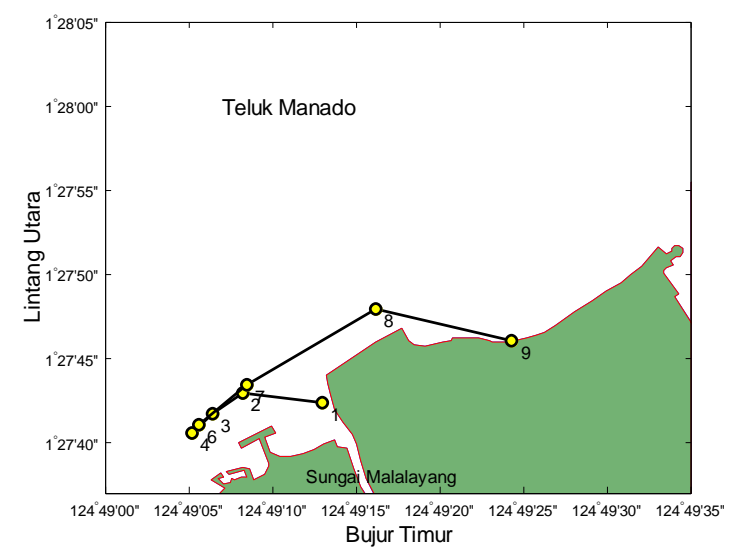

Gambar 5. Aliran air rata pada tanggal 23 Oktober 2014 pelepasan A

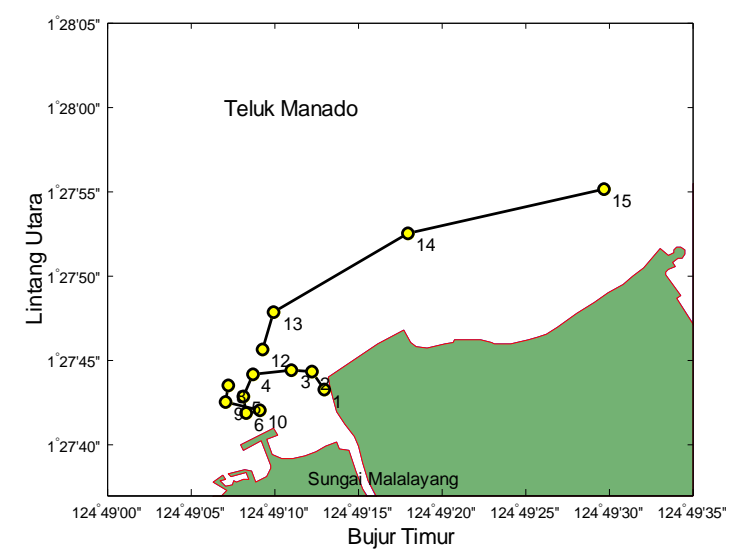

Gambar 7. Aliran air rata pada tanggal 24 Oktober 2014 pelepasan A

Pergerakan massa air pada saat air bergerak surut cenderung tidak stabil. Pada permulaan periode, massa air cenderung bergerak ke arah kiri dari mulut sungai atau ke arah barat (Gbr. 5\&7). Arah pergerakan ini mungkin merupakan pergerakan sisa pada periode air pasang, sebab menurut Rampengan (2009), air di bagian teluk ini mengalir ke arah barat pada saat pasang. Selain itu, pergerakan ini cenderung bersifat chaotic yakni pegerakan yang tidak beraturan (Gbr. 7). Hal yang sama telah diamati oleh Tulungen dkk. (2012) di perairan pantai Tateli Weru. Pergerakan yang tidak beraturan ini merupakan akibat dari interaksi antara arus dengan kondisi fisik garis pantai dan topografi dasar perairan (Lewis, 1997). Menjelang pertengahan periode surut, aliran

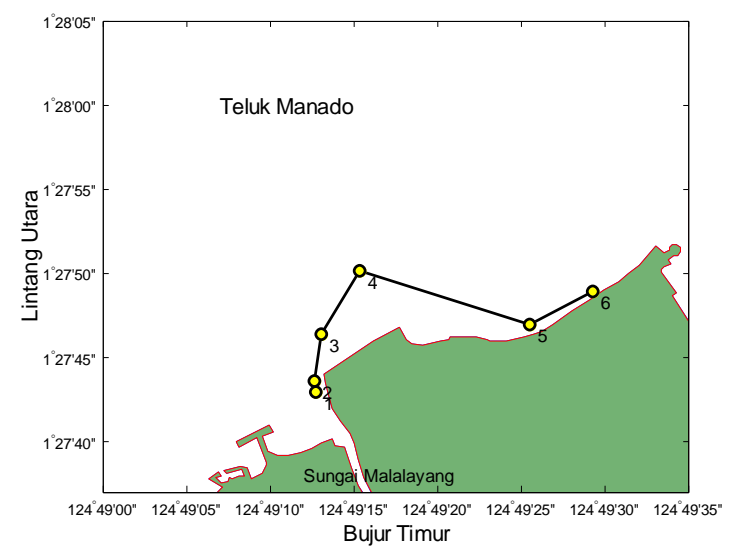

Gambar 6. Aliran air rata pada tanggal 23 Oktober 2014 pelepasan B

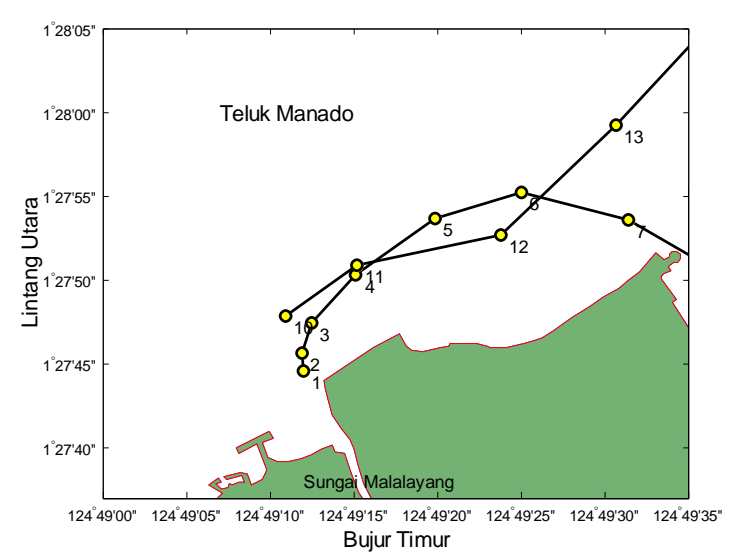

Gambar 8. Aliran air rata pada tanggal 24 Oktober 2014 pelepasan B

berbalik ke arah timur dengan kecepatan yang relatif lebih tinggi. Tidak lama kemudian, pelampung-pelampung kumpulan A ini terdampar di sepanjang pantai batu Bahu Mall.

Kumpulan B yang dilepas pada sekitar pertengahan periode surut langsung bergerak ke arah timur (Gbr. 6\&8). Pada 23 Oktober 2014 (Gbr. 5), pada awal pergerakannya, kumpulan pelampung B cenderung bergerak ke arah laut dengan jarak antar pelampung yang semakin besar. Tetapi beberapa saat kemudian, pelampungpelampung tersebut bergerak ke arah garis pantai depan Bahu Mall dengan jarak yang kembali saling berdekatan. Dua pelampung dari kumpulan ini akhirnya terdampar di batuan di pantai Bahu Mall. 
Terdamparnya pelampung-pelampung ke pantai ini sangat mungkin dipicu oleh angin, karena menurut Pond dan Pickard (1983) angin menghasilkan arus yang disebut wind-driven current. Pada saat itu angin bertiup dari arah utara cukup kencang. Tiupan angin ini mendorong massa air bergerak ke arah pantai.

Seperti yang sudah disebutkan terdahulu, dua pelampung arus kumpulan B yang dilepas pada tanggal 23 Oktober 2014 terdampar di pantai. Dua pelampung lainnya hampir terdampar, akan tetapi beberapa saat kemudian kembali bergerak menjauh dari pantai. Hal ini mungkin disebabkan oleh air yang bounced back ke arah laut, suatu mekanisme yang sama terjadi di teluk-teluk kecil atau pun kolam-kolam pelabuhan yang disebut seiches (Knauss, 1997).

Pola pergerakan pelampung-pelampung arus pada 24 Oktober 2014, secara umum mirip dengan pergerakan pada tanggal sebelumnya. Pelampungpelampung bergerak ke arah barat dan chaotic pada awal periode surut, kemudian berbalik ke arah timur di sisa periode. Namun demikian, perpindahan pelampung-pelampung arus pada 24 Oktober 2014 lebih jauh karena pelampungpelampung ini tidak terdampar mungkin karena angin utara pada waktu itu kurang kencang. Namun demikian, ada yang terperangkap di teluk Wisata Bahari. Saat beberapa pelampung terperangkap dan sulit dijangkau dengan perahu, semua pelampung dalam kumpulan diangkat dan kemudian dilepaskan lagi dalam satu kumpulan di suatu titik dekat muara sungai dan dianggap sebagai suatu pengamatan baru, seperti yang ditampilkan pada Gbr. 7 dan 8 .

\section{KESIMPULAN}

Pada periode surut, air bergerak ke arah barat pada awal periode, kemudian bergerak ke arah timur laut pada sebagian besar sisa periode. Secara umum, pola pergerakan massa air cenderung searah garis pantai, kecuali di tempat yang sangat dekat muara pergerakan cenderung chaotic.

\section{DAFTAR PUSTAKA}

Garrison, T. 2004. Essentials of Oceanography. Brooks/Cole, Australia.

Garvine, R.W. 1974. Physical features of the Connecticut River outflow during high discharge. Journal of Geophysical Research 79(6): 831-846.

Gerin, R., P.-M. Poulain, S.T. Besiktepe dan P. Zanasca. 2013. On the surface circulation of the Marmara Sea as deduced from drifters. Turkish Journal of Earth Sciences 22: 919-930.

Geyer, W.R. 1997. Influence of wind on dynamics and flushing of shallow estuaries. Estuarine, Coastal and Shelf Science 44(6): 713-722.

Gunarso, W. 1985. Tingkah laku Ikan Hubungannya dengan Metode dan Teknik Penangkapan. Jurusan Pemenfaatan Sumberdaya Perikanan. Fakultas Perikanan Institut Pertanian Bogor.

Kalangi, P.N.I. 2000. Surface divergence in Port Phillip Bay. Jurnal Fakultas Perikanan Unsrat II(1):34-38.

Knauss, J.A. 1997. Inroduction to Physical Oceanography. Prentice Hall, Upper Sadle River.

Laevastu, T. dan M.L. Hayes. 1982. Fisheries Oceanography and Ecology. Fishing News Books, Farnham. 199 hal.

Lewis, R. 1997. Dispersion in Estuaries and Coastal Waters. Wiley, Chichester.

Nasution, S. 2009. Metode Research (Penelitian Ilmiah). Bumi Aksara, Jakarta.

Pickard, G.L. dan W.J. Emery. 1990. Descriptive Physical Oceanography An Introduction. $5^{\text {th }}$ edition. Butterworth Heinemann, Oxford.

Pond, S. dan G.L. Pickard. 1983. Introductory Dynamical Oceanography. Pergamon Press, Oxford.

Rampengan, R.M. 2009. Pengaruh pasang surut pada pergerakan arus permukaan di Teluk Manado. Jurnal Perikanan dan Kelautan V(3): 15-19.

Tulungen, D., P.N.I. Kalangi dan W. Patty. 2012. Kajian pola arus di daerah penangkapan bagan apung di Desa Tateli Weru. Jurnal Ilmu dan Teknologi Perikanan Tangkap $1(2): 27-32$.

van Aken, H.M. 2002. Surface currents in the Bay of Biscay as observed with drifters between 1995 and 1999. DeepSea Research I(49): 1071-1086. 